\title{
HUBUNGAN ANTARA PERBEDAAN PERMANEN DAN PERBEDAAN WAKTU DENGAN PERSISTENSI LABA
}

\author{
Sheila Ajrina \\ Alumni Fakultas Ekonomi Universitas Negeri Jakarta \\ Santi Susanti, S.Pd., M.Ak. \\ Dosen Fakultas Ekonomi Universitas Negeri Jakarta \\ Achmad Fauzi, S.Pd., M.Ak. \\ Dosen Fakultas Ekonomi Universitas Negeri Jakarta
}

\begin{abstract}
The purpose of this research is to examine the correlation of permanent differences and timing differences with earning persistence at manufacturing companies listed in Indonesia Stock Exchange in 2013. This research used the survey method with correlational approach using secondary data which was obtained from manufacturing companies listed in Indonesian Stock Exchange. The results of this research indicate that (i) permanent differences and timing differences simultaneously had a significant correlation with earning persistence, (ii) permanent differences had a negative significant correlation with earning persistence and, (iii) timing differences had a negative significant correlation with earning persistence. The conclusion of the research is information in timing and permanent differences had opposite direction of correlation with earning persistence, which is when timing and permanent differences partially increased, the earning persistence will be decreased and timing and permanent differences simultaneously had enough rate of correlation with earning persistence.
\end{abstract}

Keywords: Permanent Differences, Timing Differences, Earning Persistence.

\section{PENDAHULUAN}

Laba merupakan elemen yang menjadi pusat perhatian utama oleh para pemakai laporan keuangan. Angka laba diharapkan dapat merepresentasikan kinerja suatu perusahaan secara keseluruhan. Informasi yang terkandung dalam laba memiliki peran yang penting bagi pihak-pihak yang berkepentingan terhadap suatu perusahaan.

Perusahaan manufaktur yang terdaftar di Bursa Efek Indonesia (BEI) sampai tahun
2013 masih menyelenggarakan pembukuan atau menyusun laporan keuangan komersial berdasarkan standar yang beraku di Indonesia, yaitu standar akuntansi keuangan, dan menyusun laporan keuangan fiskal berdasarkan peraturan perundang-undangan perpajakan yang berlaku di Indonesia. Berasal dari hal tersebut kemudian muncul istilah laporan keuangan komersial (akuntansi) dan laporan keuangan fiskal (pajak) yang menyebabkan perbedaan 
jumlah antara penghasilan sebelum pajak (laba akuntansi) dengan penghasilan kena pajak (laba fiskal) atau disebut juga dengan book tax difference.

Informasi book tax difference dapat mempengaruhi laba perusahaan di masa mendatang dan dapat menikam praktik manajemen laba yang mengindikasikan bahwa perusahaan memiliki kualitas laba yang buruk dan kurang persisten.Oleh karena itu kualitas laba menjadi pusat perhatian bagi investor, kreditor, pembuat kebijakan akuntansi, dan pemerintah.

Salah satu yang memengaruhi persistensi laba adalah pembayaran pajak yang ditanggung berdasarkan pajak pendapatan perusahaan. Rekonsiliasi fiskal di akhir periode pembukuan menyebabkan terjadinya perbedaan antara laba fiskal dan laba akuntansi. Perbedaan tersebut disebabkan oleh ketentuan pengakuan dan pengukuran yang berbeda antara standar akuntansi keuangan dan peraturan pajak. Penyebab perbedaan tersebut secara umum dikelompokkan ke dalam perbedaan waktu (timing differences) dan perbedaan tetap (permanent differences). Adapun tujuan rekonsiliasi pajak adalah untuk mengetahui dan mengakui besarnya laba kena pajak sebagai dasar pengenaan pajak penghasilan sehingga diperoleh pajak penghasilan yang terutang sesuai dengan undang-undang dan ketentuan perpajakan. Perbedaan antara laba akuntansi dan laba fiskal yang dipengaruhi oleh perbedaan permanen dan perbedaan waktu dapat memberikan informasi mengenai kualitas laba. Logika yang mendasarinya adalah adanya sedikit kebebasan akuntansi yang diperbolehkan dalam pengukuran laba fiskal.

Metode akuntansi pajak penghasilan yang berorientasi pada neraca mengakui kewajiban dan aktiva pajak tangguhan terhadap konsekuensi fiskal masa depan yang disebabkan oleh adanya perbedaan temporer dan sisa kerugian yang belum dikompensasikan. Untuk itu, perbedaan temporer yang dapat menambah jumlah pajak di masa depan akan diakui sebagai hutang pajak tangguhan (deferred tax 
liabilities), dan perusahaan harus mengakui adanya beban pajak tangguhan, yang berarti bahwa kenaikan hutang pajak tangguhan konsisten dengan perusahaan yang mengakui pendapatan lebih awal atau menunda biaya untuk pelaporan keuangan dibanding pelaporan pajak. Sebaliknya, perbedaan permanen yang dapat mengurangi jumlah pajak di masa depan akan diakui sebagai aktiva pajak tangguhan (deferred tax asset) dan perusahaan harus mengakui adanya manfaat pajak tangguhan, yang berarti bahwa kenaikan aktiva pajak tangguhan konsisten dengan perusahaan yang mengakui biaya lebih awal atau menangguhkan pendapatannya untuk tujuan pelaporan keuangan dibanding pelaporan pajak.

Persistensi laba akuntansi adalah revisi dalam laba akuntansi yang diharapkan di masa depan yang diimplikasi oleh laba akuntansi tahun berjalan. Besarnya revisi ini menunjukkan tingkat persistensi laba. Persistensi laba merupakan salah satu komponen nilai prediktif laba, maka beberapa informasi yang berupa perbedaan permanen dan perbedaan waktu mampu mempengaruhi laba bersih perusahaan yang dapat mempengaruhi persistensi laba, serta dapat membantu investor dalam menentukan kualitas laba dan nilai perusahaan.

\section{METODOLOGI PENELITIAN}

\section{Objek dan Ruang Lingkup Penelitian}

Objek dari penelitian ini adalah Perbedaan Permanen, Perbedaan Waktu, dan Persistensi Laba. Penelitian dilakukan dengan mengambil data laporan keuangan pada Perusahaan Manufaktur yang terdaftar di Bursa Efek Indonesia (BEI) yang sudah diaudit tahun 2013.

\section{Metode Penelitian}

Dalam analisis data, metode yang digunakan adalah metode survey dengan pendekatan korelasional menggunakan data sekunder, yaitu untuk mengetahui seberapa jauh hubungan yang terjadi antar variabel yang diteliti dengan memperhatikan besaran koefisien korelasi. 
Populasi dan Sampel

Populasi dalam penelitian ini adalah seluruh perusahaan manufaktur yang terdaftar di Bursa Efek Indonesia (BEI) tahun 2013 yaitu sebanyak 136 perusahaan. Selanjutnya populasi terjangkau diambil dari populasi yang memenuhi kriteria. Adapun kriteria yang digunakan adalah: Perusahaan tidak mengalami kerugian dalam laporan keuangan komersial dan laporan keuangan pajak karena kerugian dapat dikompensasi ke masa depan (carryforward). Hasil dari penentuan populasi yang memenuhi kriteria yaitu sebanyak 73 perusahaan manufaktur. berdasarkan tabel penentuan Isaac dan Michael dengan taraf kesalahan sebesar 5\%, diperoleh 65 perusahaan yang dipilih menjadi anggota sampel.

\section{Operasionalisasi Variabel Penelitian}

\section{Perbedaan Permanen}

Definisi Konseptual

Perbedaan permanen adalah perbedaan pengakuan suatu penghasilan atau biaya berdasarkan ketentuan peraturan perundang-undangan perpajakan dengan prinsip akuntansi yang sifatnya permanen. Transaksi yang diakui oleh Wajib Pajak sebagai penghasilan atau sebagai biaya sesuai akuntansi secara komersial, tetapi berdasarkan ketentuan peraturan perpajakan, transaksi dimaksud bukan merupakan penghasilan atau bukan merupakan biaya, atau sebagian merupakan penghasilan atau sebagian merupakan biaya.

\section{Definisi Operasional}

Perbedaan permanen sebagai variabel bebas (X1) diperoleh dari jumlah perbedaan permanen yang tersaji pada catatan atas laporan keuangan dibagi dengan total aset yang terdapat pada laporan keuangan publikasi di Bursa Efek Indonesia (BEI) yang telah diaudit tahun 2013 .

Beda

Permanen

Jumlah Beda Permanen

Total Aset

Perbedaan Waktu

Definisi Konseptual 
Perbedaan waktu adalah perbedaan yang terjadi karena perbedaan waktu pengakuan pendapatan dan beban tertentu menurut akuntansi atau ekonomi perusahan dengan ketentuan perpajakan yang bersifat sementara, yang mengakibatkan penggeseran pengakuan penghasilan dan biaya antara satu tahun pajak ke tahun pajak lainnya.

\section{Definisi Operasional}

Perbedaan waktusebagai variabel bebas (X2) diperoleh dari jumlah perbedaan waktu yang tersaji pada catatan atas laporan keuangan dibagi dengan total aset yang terdapat pada laporan keuangan publikasi di Bursa Efek Indonesia (BEI) yang telah diaudit tahun 2013.

Beda Waktu $=\frac{\text { Jumlah Beda } \text { Waktu }}{\text { Total Aset }}$

Persistensi Laba

\section{Definisi Konseptual}

Persistensi laba adalah laba bersih tahun berjalan yang sekiranya dapat berkelanjutan di masa depan dan berguna untuk peramalan laba atau arus kas.

\section{Definisi Operasional}

Persistensi labasebagai variabel terikat (Y) diukur menggunakan koefisien regresi antara laba akuntansi sebelum pajak satu periode masa depan dengan laba akuntansi sebelum pajak periode sekarang dibagi total aset yang jumlah nominalnya terdapat pada laporan keuangan publikasi di Bursa Efek Indonesia (BEI) yang telah diaudit tahun 2013 atau disebut juga dengan earnings dynamic formula, yaitu:

$$
\mathrm{oX}_{\mathrm{t}}^{\mathrm{a}}=\operatorname{\omega oX}_{\mathrm{t}-1}{ }^{\mathrm{a}}+\mathrm{V}_{\mathrm{t}-1}+\varepsilon_{\mathrm{t}}
$$

Keterangan:

$\mathrm{ox}_{\mathrm{t}}{ }^{\mathrm{a}}=$ persistensi laba sebelum pajak periode sekarang

$$
\begin{aligned}
& \operatorname{ox}_{\mathrm{t}-1}{ }^{\mathrm{a}}=\text { koefisien laba sebelum } \\
& \text { pajak satu periode ke belakang } \\
& \text { dengan syarat } 0<\omega<1 \\
& \mathrm{~V}_{\mathrm{t}-1}=\text { variabel yang mempengaruhi }
\end{aligned}
$$
persistensi laba satu periode ke 


\begin{tabular}{|c|c|c|}
\hline belakang (jika & $\mathrm{V}_{\mathrm{t}-1} \quad$ belum & Keterangan : \\
\hline diikutsertakan $=0$ ) & & $=$ konstanta persamaan regresi \\
\hline$\varepsilon_{\mathrm{t}}=$ standar error. & & b1, b2 = koefisien regresi \\
\hline
\end{tabular}

\section{Teknik Analisis Data}

\section{Uji Asumsi Klasik}

Penelitian ini menggunakan metode analisis

Uji asumsi klasik dilakukan untuk regresi berganda melalui bantuan SPSS versi 16. Data yang dikumpulkan dalam penelitian ini diolah kemudian dianalisis dengan alat statistik sebagai berikut:

\section{Uji Statistik Deskriptif}

Uji statistik deskriptif digunakan untuk memberikan gambaran umum atau karakteristik data yang digunakan dalam penelitian. Deskripsi suatu data dapat dilihat dari nilai rata-rata (mean), standar deviasi, nilai maksimum, dan nilai minimum.

\section{Persamaan Regresi Berganda}

Menurut Duwi Priyatno (2008), Regresi linier berganda adalah persamaan regresi linier ganda yang bertujuan untuk mengetahui hubungan antara kedua variabel penelitian. Persamaan regresi dalam penelitian ini sebagai berikut:

Persistensi $\mathrm{Laba}=\mathrm{a}+\mathrm{b}_{1}$ Perbedaan Permanen $+b_{2}$ Perbedaan Waktu

mengetahui apakah model regresi yang diperoleh dapat menghasilkan estimator linier yang BLUE (Best Linear Unbiased Estimator). Pengujian asumsi tersebut terdiri dari uji normalitas, uji linearitas, uji multikolinearitas, uji autokorelasi, dan uji heteroskedastisitas.

\section{Pengujian Hipotesis}

Penelitian ini menggunakan metode analisis regresi berganda. Analisis regresi berganda bertujuan untuk mengukur kekuatan hubungan tiga variabel atau lebih dan menunjukkan arah hubungan antara variabel dependen dengan variabel independen.

\section{HASIL DAN PEMBAHASAN}

\section{Persamaan Regresi Berganda}

Persamaan yang digunakan adalah regresi linier berganda yang bertujuan untuk mengetahui apakah terdapat hubungan 
antara variabel $\mathrm{X}_{1}$ dan $\mathrm{X}_{2}$ dengan variabel $\mathrm{Y}$. Analisis regresi linier berganda menghasilkan persamaan regresi yaitu :

$$
\hat{Y}=0,161-2,473 X_{1}-2,496 X_{2}
$$

Interpretasi dari persamaan tersebut adalah nilai konstan sebesar 0,161 menunjukkan bahwa apabila tidak ada variabel Perbedaan Permanen dan Perbedaan Waktu $\left(\mathrm{X}_{1}\right.$ dan $\left.\mathrm{X}_{2}=0\right)$, maka persistensi laba perusahaan sebesar 0,161 sebelum atau tanpa adanya variabel $\mathrm{X}_{1}$ dan $\mathrm{X}_{2}$. Nilai parameter atau koefisien arah regresi $\mathrm{X}_{1}$ sebesar $-2,473$ menunjukkan bahwa setiap kenaikan Perbedaan Permanen Rp.1 dengan konstanta 0,161 persistensi laba akan menurun sebesar 2,473. Nilai koefisien regresi arah $\mathrm{X}_{2}$ yang didapat adalah -2,496 artinya setiap kenaikan Perbedaan Waktu Rp.1 dengan konstanta 0,161 maka akan menurunkan persistensi laba sebesar 2,496.

\section{Uji Asumsi Klasik}

\section{Uji Normalitas Galat Taksiran}

Pengujian normalitas galat taksiran $\mathrm{X}_{1}$ atas $\mathrm{Y}$ dan $\mathrm{X}_{2}$ atas $\mathrm{Y}$ dilakukan dengan menggunakan uji Lilliefors dengan menggunakan taraf signifikansi 0,05.

Berdasarkan hasil perhitungan uji Lilliefors dapat disimpulkan bahwa galat taksiran regresi $\mathrm{X} 1$ atas $\mathrm{Y}$ berdistribusi normal. Hal tersebut dapat dibuktikan dengan perhitungan $L_{\text {hitung }}=0,10962$ sedangkan nilai $L_{\text {tabel }}=0,10989$ yang artinya $L_{\text {hitung }}<L_{\text {tabel }}$. Begitu pula dengan galat taksiran regresi $\mathrm{X} 2$ atas $\mathrm{Y}$ juga berdistribusi normal. Hal tersebut dapat dibuktikan dengan perhitungan $L_{\text {hitung }}=$ 0,03769 sedangkan nilai $L_{\text {tabel }}=0,10989$ yang artinya $L_{\text {hitung }}<L_{\text {tabel }}$ -

\section{Uji Normalitas Galat Taksiran Regresi}

\section{Ganda}

Berdasarkan hasil perhitungan uji Lilliefors dapat disimpulkan bahwa galat taksiran regresi $\mathrm{Y}$ atas $\mathrm{X}$ berdistribusi normal. Hal tersebut dapat dibuktikan dengan perhitungan $L_{\text {hitung }}=0,07088$ sedangkan nilai $L_{\text {tabel }}=0,10989$ yang artinya $L_{\text {hitung }}<L_{\text {tabel }}$

\section{Uji Linearitas Regresi}


Untuk mengetahuinya, dilakukan uji variabel Perbedaan Permanen dan linearitas dengan program SPSS yaitu Perbedaan Waktu tidak berkorelasi satu melalui Compare Means. Hasil dari uji sama lain.

linearitas yang dilakukan pada variabel $X_{1} \quad$ Uji Autokorelasi

terhadap Y memiliki nilai signifikansi uji Untuk mendeteksi ada tidaknya linieritas sebesar 0,024. Karena nilai ini autokorelasi yaitu dengan melakukan uji lebih kecil dari 0,05 maka variabel $\mathrm{X}_{1}$ dinyatakan terdapat hubungan linear dengan variabel Y. Demikian pula dengan variabel $\mathrm{X}_{2}$ terhadap $\mathrm{Y}$ yang memiliki nilai signifikansi uji linearitas sebesar 0,000 . Karena nilai ini lebih kecil dari 0,05 maka variabel $\mathrm{X}_{2}$ dinyatakan terdapat hubungan linear dengan variabel $\mathrm{Y}$.

\section{Uji Multikolinieritas}

Untuk mendeteksi apakah terjadi masalah multikolinieritas dapat melihat nilai toleransi dan variance inflation factor (VIF). Diperoleh hasil bahwa tidak terjadi multikolinieritas dengan dasar nilai VIF sebesar 4,498 untuk setiap variabel independen dan tidak ada yang melebihi nilai 10 sedangkan untuk nilai toleransi sebesar 0,222 dan tidak ada yang kurang dari 0,1. Hal ini menunjukkan bahwa

Durbin-Watson.

Nilai Durbin Watson (DW) sebesar 1,847 akan dibandingkan dengan nilai tabel Durbin Watson menggunakan signifikansi $5 \%$, jumlah sample 65 dan jumlah variabel independen 2 didapat nilai batas bawah (dL) sebesar 1,536 nilai batas atas (dU) sebesar 1,662 dan nilai 4-dU sebesar 2,338. Nilai DW yang diperoleh sebesar 1,847 berada di antara dU dan 4-dU maka dapat disimpulkan tidak terjadi gejala autokorelasi.

\section{Uji Heteroskedastisitas}

Berikut ini adalah hasil olahan data untuk Uji Heteroskedastisitas dengan menggunakan program SPSS: Dari data yang telah diolah menggunakan uji Glejser diperoleh nilai probabilitas signifikansi Perbedaan Permanen sebesar 0,119 dan Perbedaan Waktu sebesar 0,575. Hal ini 
terlihat dari probabilitas signifikansinya di atas tingkat kepercayaan 0,05 maka Ho diterima dan tidak terjadi gejala heteroskedastisitas.

\section{Pengujian Hipotesis}

Uji Koefisien Korelasi Simultan (Uji-F)

Berdasarkan hasil perhitungan uji ANOVA menunjukkan bahwa $F_{\text {hitung }}>F_{\text {tabel }}$ atau $11,288>3,143$. Jadi, dapat disimpulkan bahwa Perbedaan Permanen dan Perbedaan Waktu secara bersama-sama berpengaruh terhadap Persistensi Laba.

\section{Uji Koefisien Korelasi Parsial (Uji-T)}

Hasil perhitungan menunjukkan bahwa $t_{\text {hitung }}$ Perbedaan Permanen sebesar 2,114 dengan $t_{\text {tabel }}$ sebesar 1,997. Jadi, Uji Koefisien Determinasi

Besarnya Adjusted $R$ Square adalah 0,243 maka dapat disimpulkan bahwa Persistensi Laba dipengaruhi oleh Pembahasan Hasil Penelitian

Berdasarkan hasil pengolahan data yang dilakukan terhadap perusahaan-manufaktur yang terdaftar di BEI yang menerbitkan laporan tahunan secara lengkap selama $t_{\text {hitung }}>t_{\text {tabel maka Ho ditolak sehingga }}$ dapat disimpulkan bahwa variabel Perbedaan Permanen memiliki kontribusi terhadap Persistensi Laba. Nilai $\mathrm{t}$ negatif menunjukkan bahwa Perbedaan Permanen mempunyai hubungan yang berlawanan arah dengan Persistensi Laba.

Hasil perhitungan $t_{\text {hitung }}$ Perbedaan Waktu sebesar 2,172 dengan $t_{\text {tabel }}$ sebesar 1,997. Jadi, $t_{\text {hitung }}>t_{\text {tabel }}$ maka Ho ditolak sehingga dapat disimpulkan bahwa variabel Perbedaan Waktu memiliki kontribusi terhadap Persistensi Laba. Nilai t negatif menunjukkan bahwa Perbedaan Waktu mempunyai hubungan yang berlawanan arah dengan Persistensi Laba.

Perbedaan Permanen dan Perbedaan Waktu sebesar $24,3 \%$. Sedangkan sisanya sebesar $75,7 \%$ dapat dipengaruhi oleh variabel lain.

tahun 2013 serta tidak mengalami kerugian dalam laporan keuangan komersial maupun laporan keuangan pajak, penulis akan membahas hasil penelitian yang dilakukan 
sesuai dengan permasalahan yang telah diajukan.

Menurut perhitungan statistik dengan SPSS di atas, hasil penelitian untuk hipotesis pertama menunjukkan bahwa perbedaan permanen secara negatif saling berhubungan signifikan terhadap persistensi laba. Perbedaan permanen mempunyai hubungan yang berlawanan arah dengan persistensi laba, di mana saat beda permanen meningkat maka akan menurunkan persistensi laba perusahaan. Kondisi ini terjadi dikarenakan oleh komponen penyusun variabel permanen itu sendiri, yaitu item penghasilan atau biaya yang berpengaruh terhadap laba akuntansi tetapi tidak akan mempengaruhi laba fiskal, dan sebaliknya secara tetap atau selamanya. Setiap tahun, item-item perbedaan permanen yang dimiliki perusahaan akan bertambah maupun berkurang nominalnya dalam rekonsiliasi fiskal sesuai dengan kondisi perusahaan. Salah satu contoh item perbedaan permanen adalah pemberian kenikmatan atau natura seperti yang disebutkan dalam Undang Undang Pajak Penghasilan Nomor 36 Tahun 2008 Pasal 9 Ayat (1) huruf e.

Kondisi lainnya yang menyebabkan perbedaan permanen nilainya berubah sehingga mempengaruhi persistensi laba perusahaan yaitu kondisi di mana komponen penyusun perbedaan permanen itu sendiri merupakan item yang sifatnya tidak berulang (non-recurring). Kondisi ini sama dengan yang dijabarkan oleh penelitian Martini dan Persada di tahun 2008 bahwa hasil koefisien negatif menunjukkan bahwa perbedaan permanen didominasi oleh itemitem yang akan ditambahkan kembali dalam rekonsiliasi fiskal yaitu beban yang tidak dapat dikurangkan atau kerugian anak perusahaan dan bersifat nonrecurring item .

Naik atau turunnya nilai suatu komponen penyusun perbedaan permanen, akan mempengaruhi persistensi laba perusahaan satu periode ke depan. Jika jumlah perbedaan permanen meningkat dari tahun sebelumnya, maka pajak yang akan dibayarkan juga akan menjadi lebih besar 
nilainya. Besarnya pajak yang harus dibayarkan akan mengurangi laba laba.

perusahaan tersebut dan mempengaruhi persistensi labanya.

Hasil penelitian ini konsisten dengan penelitian-penelitian sebelumnya, yaitu pada penelitian Martini dan Persada di tahun 2008. Penelitian yang dilakukan Martini dan Persada memberikan hasil yaitu variabel permanen menunjukkan nilai yang signifikan secara statistik. Variabel ini juga menunjukkan nilai koefisien yang negatif, artinya bahwa variabel permanen memiliki korelasi negatif terhadap persistensi laba.

Teori dari Rosanti dan Zulaikha dalam penelitiannya pada tahun 2013 pun mendukung hasil dari penelitian ini. Rosanti dan Zulaikha menyatakan bahwa perbedaan tetap mengakibatkan book income berbeda secara tetap dengan taxable income. Jika laba fiskal bertambah, beban pajak akan semakin besar maka akan semakin kecil laba bersihnya, begitupun sebaliknya. Oleh karena itu, perbebedaan permanen berpengaruh negatif terhadap persistensi

Hasil penelitian untuk hipotesis kedua menunjukkan bahwa perbedaan waktu secara negatif saling berhubungan signifikan terhadap persistensi laba. Perbedaan waktu sama sifatnya dengan perbedaan permanen, yaitu memiliki hubungan yang berlawanan arah dengan persistensi laba, di mana saat beda waktu meningkat maka akan menurunkan persistensi laba perusahaan. Kondisi ini terjadi akibat dari pembalikan atas dasar perbedaan waktu di masa yang akan datang sehingga perbedaan waktu memiliki hubungan negatif terhadap persistensi laba. Perbedaan waktu pada penelitian ini didominasi oleh perbedaan waktu dengan koreksi fiskal positif yang menyebabkan laba fiskal bertambah. Semakin besar jumlah laba fiskal, maka semakin besar beban pajak yang harus dibayarkan. Semakin besar pajak yang harus dibayar, semakin kecil laba bersih yang dihasilkan. Hasil penelitian ini sesuai dengan penelitian sebelumnya yang 
menyatakan bahwa perbedaan waktu persistence in pre-tax earnings. Namun memiliki hubungan negatif signifikan Hanlon selanjutnya menguraikan laba ke terhadap persistensi laba, yaitu dalam dalam arus kas dan akrual. Hasilnya, firm penelitian Martini dan Persada di tahun years wuth large positive temporary 2008, penelitian Hanlon di tahun 2005, dan penelitian Suwandika dan Astika di tahun 2013.

difference have lower earnings and accrual persistence consistent with these firm having a higher level of discretionary accruals.

Martini dan Persada menyebutkan bahwa perbedaan antara dasar pengenaan pajak dari suatu aktiva atau kewajiban akan berakibat pada kenaikan atau bertambahnya laba fiskal periode mendatang atau berkurangnya laba fiskal periode mendatang, pada saat nilai tercatat aktiva dipulihkan atau nilai tercatat kewajiban diselesaikan atau dilunasi. Hasil penelitian ini juga didukung oleh teori dari Lumbantoruan yang menuliskan bahwa beda waktu mengakibatkan penggeseran pengakuan penghasilan dan biaya antara satu tahun pajak ke tahun pajak lainnya, sehingga mempengaruhi persistensi laba perusahaan.

Penelitian yang dilakukan Hanlon juga menjabarkan bahwa the firm with large positive temporary difference have lower fiskal positif berarti laba pajak lebih besar dibandingkan dengan laba akuntansi atau laba komersial. Hal ini berarti mayoritas perusahaan manufaktur di Indonesia memiliki liabilitas pajak tangguhan yang tinggi. Menurut Revsine, peningkatan liabilitas pajak tangguhan memungkinkan adanya indikasi penurunan kualitas laba yang dibentuk dari persistensi laba. Dengan kata lain, penelitian ini sesuai dengan teori yang telah dikemukakan oleh Revsine.

Kemudian hasil penelitian untuk hipotesis yang ketiga menunjukkan bahwa perbedaan permanen dan perbedaan waktu secara bersama-sama berpengaruh terhadap persistensi laba dengan tingkat keeratan cukup. Persistensi laba dipengaruhi oleh 
perbedaan permanen dan perbedaan waktu sebesar 24,3\%. Kondisi ini terjadi karena perbedaan permanen dan perbedaan waktu secara bersama-sama dapat menunjukkan adanya campur tangan yang berlebih pada manajemen dengan memanfaatkan celah yang ada dalam standar akuntansi keuangan untuk menentukan besarnya laba akuntansi. Campur tangan yang dimaksud yaitu bahwa manajemen memiliki kewenangan yang besar untuk menentukan besarnya pos-pos yang mengakibatkan timbulnya beban pajak tangguhan seperti pemulihan atau penyisihan piutang tak tertagih dan pemulihan atau penyisihan atas imbalan kerja karyawan. Peraturan perpajakan yang tidak mengakui penyisihan piutang tak tertagih dapat membuat manajemen memanfaatkan hal tersebut dan piutang tak tertagih akan diakui oleh peraturan perpajakan ketika daftar piutang tak tertagih yang dimiliki Wajib Pajak diserahkan kepada Dirjen Pajak dan piutang tersebut pada laporan laba rugi komersial telah diakui sebagai beban. Terealisasinya beban pajak tangguhan di masa depan oleh kedua hal tersebut mengakibatkan beban pajak tangguhan dapat mengurangi laba akuntansi sehingga berpengaruh pada laba sebelum pajak tahun depan. Hasil penelitian yang diperoleh sejalan dengan penelitian Suwandika pada tahun 2013, bahwa perbedaan permanen dan perbedaan waktu secara bersama-sama mempengaruhi persistensi laba.

Hasil penelitian Wijayanti pada tahun 2006 mengatakan bahwa perbedaan permanen dan perbedaan waktu secara simultan berpengaruh signifikan secara statistik terhadap laba akuntansi satu periode ke depan. Kondisi ini terjadi akibat subjektivitas dalam proses akrual untuk tujuan pelaporan keuangan dibandingkan untuk tujuan pajak. Wijayanti juga memberikan asumsi bahwa yang mendasari penelitian book tax differences untuk menilai persistensi laba, yaitu terdapat variasi cross sectional dalam kemampuan manajer untuk memanipulasi pelaporan laba akuntansi namun tidak dalam pelaporan laba 
kena pajak. Pada akhirnya, manajer lebih senang meningkatkan laba akuntansi tanpa menyebabkan peningkatan pada laba fiskal dengan memanfaatkan keleluasaan peraturan akuntansi. Teori yang dikemukakan Wijayanti sejalan dengan teori yang diungkapkan oleh Revsine bahwa "berkurangnya saldo aktiva pajak tangguhan harus diinvetigasi lebih lanjut, karena perubahan dalam hubungannya dengan akun neraca mungkin digunakan sebagai suatu cara untuk menaikkan laba secara semu."

\section{DAFTAR PUSTAKA}

Aruna Dian Citra, Jaya Tresno Eka, dan Santi Susanti, 2008. Akuntansi Pajak di Indonesia.Jakarta: UNJ Press.

Hanlon, Michelle. 2005. "The Persistence and Price of Earnings, Accruals, and Cash Flows When Firms Have Large Book-Tax Differences."The Accounting Review. Vol.80, No.1, hal. 145.

Keown, Martin, et.al, 2008. Manajemen Keuangan: Prinsip dan Penerapan. Edisi Kesepuluh. Jilid 1. Jakarta: PT Indeks.

Lumbantoruan, Sophar, 2001. Akuntansi Pajak. Edisi Revisi. Jakarta: PT Grasindo. Martiani, Dwi dan Aulia Eka Persada, 2008. "Pengaruh Book Tax Gap terhadap Persistensi Laba". Jurnal Ilmiah Akuntansi. Vol.2, No.1, ISSN 23002559.

Palepu, Khrisna G. dan Paul M. Healy, 2008. Business Analysis and Valuation
Using Financial Statements.Canada: Thomson Learning.

Penman, H. Stephen, 2001. Financial Statement Analysis and Security Valuation. New York: McGraw-Hill.

Pramitasari, Bety, 2007. "Analisis Book Tax Differences Terhadap Persistensi Laba dan Laba Akrual Sebagai Variabel Moderating Pada Perusahaan Yang Terdaftar di Bursa Efek Indonesia." Jurnal Akuntansi \& Investasi. Vol.8 No.1.

Priyatno, Duwi, 2008. Mandiri Belajar SPSS.Yogyakarta: MediaKom.

Resmi, Siti, 2011. Perpajakan: Teori dan Kasus. Edisi 6. Buku 1.Jakarta: Salemba Empat.

Revsine, L., Collins W. D., dan W. Bruce Johnson, 2001.Financial Reporting and Analysis.New Jersey: Prentice Hall.

Rosanti, Nur Aini dan Zulaikha, 2013."Book Tax Differences Terhadap Persistensi Laba". Joui Of Accounting. Vol. 2, No. 2.

Scott, R. William, 2003. Financial Accounting Theory. Third Edition. Toronto: Prentice Hall.

Sja'roni, Teguh, 2009.Susunan Dalam Satu Naskah Undang Undang Pajak Penghasilan Sebagaimana Telah Dirubah Terakhir Dengan Undang Undang Republik Indonesia Nomor 36 Tahun 2008. Jakarta: Universitas Trisakti.

Suandy, Erly, 2003.Perencanaan Pajak. Edisi Revisi.Jakarta: Salemba Empat.

Subramanyam, K. R., dan John J. Wild, 2009. Financial Statement and Analysis. Tenth Edition. New York: McGraw-Hill.

Sugiyono, 2010. Statistika Untuk Penelitian. Bandung: Alfabeta.

Wijayanti, Tri Handayani, 2006. Analisis Pengaruh Perbedaan Antara Laba Akuntansi dan Laba Fiskal Terhadap Persistensi Laba, Akrual, dan Arus Kas. Padang: Simposium Nasional Akuntansi 9 
Zain, Mohammad, 2005. Manajemen Perpajakan.Jakarta: Salemba Empat.

Biaya Produksi Naik, Laba Kimia Farma

Turun.http://www.bumn.go.id/22072 /publikasi/berita/biaya-produksinaik-laba-kimia-farma-turun/.

(Diakses tanggal 19 April 2014 pukul 10.22).

Gunawan, Yufianto. Penjualan Nokia Jauh Menurun! 2012. (Diakses tanggal 26 April 2014 pukul 14.04).

Nokia.

http://www.manajementelekomunika si.org/2012/10/nokia.html?m=1.

(Diakses tanggal 26 April 2014 pukul 14.08).

Peningkatan Beban Keuangan Tekan Laba Bersih Garuda.

http://www.ift.co.id/posts/peningkatanbeban-keuangan-tekan-laba-bersihgaruda. (Diakses tanggal 19 April 2014 pukul 10.53).

PT Bank Permata Tbk. Penjelasan Atas Laporan Keuangan Konsolidasian, 2012.

http://www.idx.co.id/2012/forum.ht ml. (Diakses tanggal 26 April 2014 pukul 19.20).

PT Sekawan Intipratama.. (Diakses tanggal 28 April 2014 pukul 20.35).

Sutianto, Dwi Feby, 2013. Harga BBM Naik, Laba Kimia Frama Anjlok. http://finance.detik.com/read/2013/0 7/30/144252/2319028/6/harga-bbmnaik-laba-kimia-farma-anjlok-47.

(Diakses tanggal 19 April 2014 pukul 11.20). 